SEFAD, 2020; (43): 1-18

e-ISSN: 2458-908X

DOI Number: https://doi.org/10.21497/sefad.755468

\title{
Ömer Seyfettin'in “Horoz” ve “Dünyanın Nizamı” Hikâyelerini Modernizm Çerçevesinde Okumak
}

\author{
Dr. Arzu Atasoy \\ Gaziantep Üniversitesi, Eğitim Fakültesi \\ Türkçe Ĕ̆itimi Ana Bilim Dalı \\ arzuatasoy2014@outlook.com
}

\author{
Prof. Dr. Mehmet Temizkan \\ Hatay Mustafa Kemal Üniversitesi, Eğitim Fakültesi \\ Türkçe Eğitimi Ana Bilim Dalı \\ temizkan.mehmet2016@outlook.com
}

Öz

Bir eserin yazıldığı anlayışı çözümleyebilmek eserin amacını, mesajını, söylemini anlamak açısından önemlidir. Eserin zemininde bulunan anlayış çerçevesinde gerçekleştirilen okuma, analiz edilecek metne 1şık tutar. Ömer Seyfettin, hikâyelerinin incelendiği birçok araştırmada millî-manevi değerlerin inşasına katkı sunan bir yazar olarak konumlandırılmıştır. Bunda kuşkusuz yazarın Türkçülügün öncülerinden olmasının, millî edebiyat hareketinin odağında bulunmasının, yeni lisanın ilkelerini belirleyip bu ilkeler doğrultusunda eserler kaleme almasının, benimsediği öğretileri hikâyelerinde işlemesinin etkisi vardır. Oysa yazarın pek çok hikâyesine yakından bakıldığında bu hikâyelerin farklı anlayış ve arka planla yazılmış oldukları görülür. Bu çalışmanın amacı, Ömer Seyfettin'in milliyetçi-muhafazakâr bakış açısının ötesinde farklı bakış ve arka planla yazılmış hikâyelerinin de olduğunu ortaya koyarak yazarın eserlerinin farklı okumalarla incelenmesine zemin hazırlamaktır. Bu amaçla çalışmada yazarın birbirinin devamı niteliğinde olan "Horoz" ve "Dünyanın Nizamı" isimli iki hikâyesinde modernizmin izleri sürülmeye çalışılmış, elde edilen bulgular modernizm akımının temel ögeleri referans alınarak oluşturulan başlıklar altında değerlendirilmiştir. Yazarın incelenen hikâyelerinde modernizme temel teşkil edebilecek ögeler yabancılaşma, iletişimsizlik, sisyphos saçma (uyumsuz) kompleksi, anomi, pasif isyan, kahramanın silikleşmesi, arketip ve anne arketipi, freudyen unsurlar ve psikanalizm (bilinçaltı ve rüya, üstben/toplumsal uyumsuzluk, ben/toplumsal uyum, cinsellik) başlıkları altında incelenmiştir. İnceleme sonucunda "Horoz" ve "Dünyanın Nizamı" isimli hikâyeler, zengin veriler sunmaları açısından modernist unsurlarla kaleme alınmış hikâyeler olarak kabul edilmiştir.

Anahtar Kelimeler: Ömer Seyfettin, hikâye, modernizm, Sigmund Freud, psikanalitik kuram. 


\title{
Reading Ömer Seyfettin's Stories "Horoz" and "Dünyanın Nizamı" Within the Framework of Modernism
}

\begin{abstract}
Being able to analyze the understanding of a literary work is significant to understand the purpose, message and discourse of it. Ömer Seyfettin was positioned as a writer contributing to the creation of national-spiritual values in many researches examining his stories. Undoubtedly, being one of the precursors of Turkism, being the focus of the national literature movement, identifying the principles of the new language and writing up a literary work in accordance with these principles and practicing adopted teachings in his story have influence on it. In fact, by a close look at the author's stories, it is seen that these stories were written with a different understanding and background. In the stories examined within the scope of the study, the elements that could form the basis of modernism was analyzed under the headings of alienation, lack of communication, the Sisyphus Complex, anomy, passive riot, indistinctness of character, archetype and mother archetype, Freudian elements and psychoanalysis (subconscious and dream, superego / social incompatibility, ego / social harmony and sexuality). As a result of the review, the two stories "Horoz" and "Dünyanın Nizamı" were accepted to be written with modernist elements with regard to the presentation of rich data.
\end{abstract} theory.

Keywords: Ömer Seyfettin, story, modernism, Sigmund Freud, psychoanalytical 


\section{GíRIŞ}

Ömer Seyfettin, edebiyatımıza farklı türlerde pek çok eser kazandırmakla birlikte en çok hikâyeleriyle tanınır. Her şeyden bir hikâye konusu çıkarabileceğini ifade eden yazar, 36 yıllık yaşamına pek çok hikâye sığdırmıştır. Akyüz'e göre (1995) Türk edebiyatında hikâyeciliği meslek hâline getiren ve hikâye yazarlığını ayrı ve cazip bir edebî çalışma alanı olarak ortaya koyan ilk yazar Ömer Seyfettin'dir. Babası da bir asker olan Ömer Seyfettin'in ilk mesleği askerliktir. Gençliği, Osmanlı Devleti'nin bir yandan Fransız ihtilalinin etkisiyle ayaklanan azınlıkların isyanlarıyla uğraştığı diğer yandan Balkanlardaki topraklarını kaybetmemek için mücadele verdiği bir döneme denk gelmiştir. Askerî okullarda öğrenim gören Ömer Seyfettin, orduda görev almış, Yanya Kuşatması sırasında Yunanlılara esir düşmüştür. İşte böyle bir ortamda Ömer Seyfettin "Bomba", "Beyaz Lale", "Primo Türk Çocuğu" gibi hikâyeleri; "Yarınki Turan Devleti", "Türklük Mefkûresi" gibi incelemeleri kaleme almıştır. Yazarın hikâyeleri çoğunlukla millî, manevi ve İslami değerler çerçevesinde okunmuş olmasına rağmen yakından bakıldığında onun hikâyelerini modernist unsurlarla zenginleştirdiği görülür. Benzer şekilde Ömer Seyfettin'i konu alan çalışmalara baktı̆̆ımız zaman bu çalışmalarda genellikle yazarın hikâyelerinin eğitim, değerler, söz dizim unsurları açısından ele alındığını görmekteyiz. Bu çalışmada ise Ömer Seyfettin'in birbirinin devamı niteliğinde olan "Horoz" ve "Dünyanın Nizamı" isimli hikâyeleri modernist bir bakış açısıyla çözümlenmeye çalışılmıştır. Bu kapsamda öncelikle modernizmin ortaya çıkışı ve edebiyatta modernist etkiden bahsedilmiş, hikâyeleri çözümleme aşamasında da modernist eserlerin özelliklerinden yabancilaşma, iletişimsizlik, anomi, Sysiphos kompleksi, arketip, kahramanın silikleşmesi ve Freudyen unsurlar (bilinçaltı ve rüya, üstben/toplumsal uyumsuzluk, ben/toplumsal uyum ve cinsellik) bağlamında hikâyelerin içerik sorgulaması yapilmıştır.

\section{Modernizmin Ortaya Çıkışı ve Edebiyatta Modernist Etki}

Modernleşmenin hayatın her alanında kendini hissettirmesi 20. yüzyılda gerçekleşmiştir. Bu yüzyılda dünya sosyal, ekonomik, kültürel, moda vb. alanlarda büyük bir değişime uğramış ve daha iyi bir dünya' vaadiyle yeni bir düzen kurulmaya çalışılmıştır. Bu yeni düzenin kurucu unsuru akıl, yürütücü dinamiği ise rasyonalizm olmuştur. Çolak'a göre (1998, akt. Yürek, 2005, s. 18) temel ilkeleri; "değişmeye olan vurgu ve değişim hızının yüksekliği, ilerleme ve gelişmeye duyulan inanç, bilimselliğe olan güven, rasyonaliteye duyulan inanç, insana ve topluma ait her şeyin rasyonel ölçütlere vurulması" şeklinde ifade edilen modernizm bu boyutuyla insanlığa birçok alanda yeni bir algı ve yaşam tarzı teklif etmiştir.

Kendisini 20. yüzyılda iyice hissettiren modernizm bir anda ortaya çıkmış değildir. Aksine 15. yüzyıla kadar götürülebilecek çok uzun bir tarihî arka planı ve oluşum zemini vardır. Modernizmin gelişim sürecinde ortaçağ ve skolastik düşüncenin sona ermesi, rönesans ve reform hareketleri, aydınlanma çağı ve düşüncesi, sanayi devrimi ve kentleşme olgusu ile bunlara bağlı olarak ortaya çıkan bilimsel ve teknolojik gelişmeler, kapitalizm, liberalizm gibi yeni ekonomik sistemler, ulus-devletlerin yükselişi bulunmaktadır. $\mathrm{Bu}$ etkenlerin her biri beraberinde getirdiği yeni anlayış ve itki gücü taşıyan referanslarıyla modernizmin ortaya çıkışında başat roller oynamıştır.

Avrupa'da karanlık dönem olarak adlandırılan ve yaklaşık bin yıl süren ortaçağda bu döneme özgü bir düşünce sistemi gelişmiştir. Din adamlarının tekelinde kilise ve manastırlarda şekillenen ve adına skolastik denilen bu düşünce sistemi, insan aklını geri

SEFAD, 2020; (43): 1-18 
planda tutar ve dogmatik bir yaklaşımla inanç temeline dayanır. Bilimsel düşünce ve rasyonel yaklaşımı öncelemediği için aklın ürünleri olan eleştiri, sorgulama, yaratıcı ve rasyonel düşünme bu dönemde kendine gereken yeri bulamamıştır. Bu durum insan aklına güvenin esas olduğu, hayatın hemen her alanında bilimsel düşünce ve gelişmelerin egemen kılınmaya başladığı Rönesans ruhuyla sona erer. Rönesansla birlikte Antik Yunan dönemi eserleri ve düşünce sistemine yeniden dönülmüş ve hümanizm tekrar canlanmıştır. Gökberk'e göre (1999, s. 515) Rönesans Hümanizmin 'yitik insan tininin ve bilgeliğinin yeniden' ortaya çıkarılmasıyla oluşmuştur. Bu nedenle Rönesans düşüncesine kelime anlamıla uyumlu bir şekilde 'yeniden doğuş' denir. Öyleyse Rönesans daha önce yaşanmayan bir dönemin keşfi değil aslında insanlık düşüncesinde bir geriye (Antik Yunan) dönüştür. Rönesans ve Hümanizmle birlikte insan aklı ve eylemleri hayatın ekseninde yer almaya başlamıştır. Modernizm sürecinde Rönesans'ın etkisini hızlandıran başka bir gelişme de reform hareketleridir. Rönesans'ın aklın işlevselliği, bilimsel düşünce ve sanat etkinliklerinin önemsenmesi konularında getirdiği yeniliklere paralel olarak reform hareketi dinî alanda bireyleşmeyi ve özgürleşmeyi sağlamıştır. Martin Luther öncülüğünde Katolik Kilisesinin insan üzerindeki sonsuz hâkimiyetine karşı gerçekleştirilen reform hareketi, Hristiyanlık düşüncesinde Tanrı ile insan arasındaki aracıları ve engelleri kaldırmayı hedeflemiştir. Böylece insan aklına bir anlamda ipotek koyan, aforoz, enterdi ve endülijans gibi sonsuz yetkileri bulunan kilisenin etkisi kırılmış ve insan özgür bir varlık olarak kendini ifade edebilmeye başlamıştır. Böylece Rönesans ve reform hareketleri modernizmin gelişim sürecinde bir sonraki aşama olan aydınlanma düşüncesinin ortaya çıkmasını hızlandırmıştır.

Aklın ve bilimin egemenliği (Yürek, 2005,s. 26) olarak tanımlanan'aydınlanma çağı' 18. yüzyıl Avrupa coğrafyasında başta düşünce akımları olmak üzere sanat, edebiyat, sosyal hayat, bilim ve teknoloji, uluslararası ilişkiler vb. alanlarda görülen değişimin ve oluşturulan yaşam tarzının sembolüdür. Aydınlanma, "insanın düşünme ve değerlemede din ve geleneklere bağlı kalmaktan kurtulup kendi aklı, kendi görgüleri ile hayatını aydınlatmaya girişmesi"dir (Gökberk, 1999,s. 290). Aydınlanma ile birlikte insan aklının rehberliğinde siyasal sorunlar tartışılmış, doğa üzerine araştırmalar yapılarak doğanın insan hayatının pratiklerini karşılaması yönünde düzenlenmesine başlanmış, astronomi çalışmaları hızlanmış ve bilimsel icatlar ortaya konularak teknolojik gelişme sağlanmıştır. Bu durum insanla ilgili her alanda bilgi ve düşünce birikimini beraberinde getirmiş; sanata, felsefeye ayrılan zaman ve enerjiyi olumlu yönde tetiklemiştir. Böylece insan aklı, sadece izleyen ve olayları takip eden bir acziyetten kurtularak üreten ve ürettiğini kendi faydasına kullanan aktif bir düzeye ulaşmıştır. Bu gelişmeler ve ulaşılan bu düzey üretim şekilleri ve mekânlarını da etkileyerek insanlık tarihinde tüm boyutlarıyla çok önemli bir olayı yani sanayi devrimini tetiklemiştir. Sanayi devrimiyle birlikte üretim yeri topraktan fabrikaya; üretim araçları da makinelere dönüşmüştür. Böylece kırsal kesimlerden şehirlere büyük kitleler hâlinde göçler yaşanmış ve 'kentleşme' olgusu insan hayatına girmiştir. Tüm bu gelişmelerin sonucunda hayatı, dünyayı, ilişkileri, sosyal ve siyasal sistemleri ortaya koyan, yönlendiren, güncelleyen bir unsur olarak 'akıl' ön plana çıkmışır. İnsana ilişkin tüm sorunlara yine insan aklının çözüm bulacağına ve insanlığı aklın kurtaracağına olan güven artmıştır. İşte modernizm; tarihî, sosyal, siyasal, iktisadi vb. alanlardaki bu gelişmelerin neticesinde ortaya çıan ve insanı, onun eylem ve eserlerini ön plana çıkaran bu zemin üzerinde şekillenen bir yaşam tarzı olarak benimsenmiştir.

Gelişim süreci yukarıda özetlenen modernizm sanat, mimari, moda, felsefe gibi alanları derinden etkilemiştir. Edebiyat da bu alanlar arasındadır. Ancak modernizmin 
edebiyata yansıması, içerdiği referanslar doğrultusunda değil; bu referansların eleştirisi şeklinde olmuştur. Şöyle ki modernizm, aklı rehber edinmiş ve insan hayatını determinizm katılığında bir neden sonuç ilişkisine bağlamıştır. Akıl ve rasyonel düşünce her alana nüfuz etmiş, her şey yerli yerinde, belli bir sistem dâhilinde, öncelik-sonralık ilişkisine uygun biçimde işlemeye başlamıştır. Zamanla insan, üreten ancak ürettiğinin doğasını anlamayan bir varlığa dönüşmeye başlamış, yalnızlaşmış, sevgi, hoşgörü, dayanışma gibi değerler karşısında hızla yükselen 'madde' ye yenik düşmüştür. Bu durum bireyle toplum arasında bir uçurum yaratmış, çatışma ve çelişkilerin insan ruhu üzerinde yıkıcı etkilerine yol açmıştır. Birey açısından bunlar yaşanırken insana müreffeh bir hayat vaat eden insan aklı dünyayı derinden sarsan iki büyük savaşa engel olamamıştır. Böylece yalnızlaşan bireyin içinde bulunduğu ruh durumu 'kötümser' olarak belirlenmiştir. İşte modernist edebiyat; insanı geldiği bu olumsuz noktadan itibaren takip etmeye başlamış, onun iç dünyasını, toplumla çatışmalarını, çelişkilerini, yalnızlığını bilinç ve bilinçaltı unsurlarla birlikte işlemiştir.

\section{Edebiyatta Modernist Unsurlar ve Hikâye Çözümlemeleri}

Modernist edebiyat her şeyden önce insanı anlatır. Ancak modernist edebiyatta insan daha çok iç dünyasıyla vardır. Modern insan yalnızdır, kendisine ve içinde yaşadığı topluma yabancıdır. Hem kendisiyle hem de toplumla bir çatışma hâlinde olan bu insan sadece bilinç düzeyiyle değil, bilinçaltı ile hareket eder. Buna uygun olarak da yazarlar, eserlerinde insanın iç dünyasını, karmaşıklığını, bireyselliğini, yalnızlığını, huzursuzluğunu, geleneklere isyanını ve kaçışını anlatırlar. Yansıtmacı edebiyattan bu noktadaki ayrılığı modern edebiyata özgü bazı unsurların kullanılmasını gerektirmiştir. Yabancılaşma, Freudyen unsurlar, arketip, intihar, anomi bu unsurlar arasındadır.

Çalışmaya konu olan “Horoz" ve "Dünyanın Nizamı" Ömer Seyfettin'in modernist unsurları içeren ve beş gün arayla yayımlanan iki hikâyesidir. Bunlardan "Horoz", 22 Aralık 1919 tarihli Vakit gazetesinin 764. sayısında; “Dünyanın Nizamı" ise aynı gazetenin 27 Aralık 1919 tarihli 769. sayısında yayımlanmıştır. "Horoz" isimli hikâye, genç bir kızın evlenmeyi istememe kararını ve bu kararının arkasındaki gerekçeyi konu edinir. Bu hikâyede genç bir kızın, horoz ve tavukların yaşadığı kümes hayatı ile kendisi, erkek kardeşleri, anne ve babasının yaşadığı aile hayatı arasında benzerlik kurması anlatılır. Hikâyenin ilk bölümünde kümes hayatı, orada yaşayan horoz ve tavukların rolleri bağlamında genç bir kızın dilinden aktarılır. Ona göre tavuklar sevimli, kendi hâllerinde, saf, masum ve son derece fedakâr mahlûklardır. Horoz ise tavukların sahip oldukları özelliklerin aksine mağrur, zulümden başka hiçbir şeyden zevk almayan, vazife, fedakârlık, muhabbet, şefkat, merhamet nedir bilmeyen, tuvaletiyle ve nefsiyle meşgul bir gevezedir. Kümes hayatını gözlemledikçe horoza öfkesi büyüyen genç kız, yiyecek bir şey olduğunda kendisi yutan, yenmeyecek bir taş, kum parçası bulduğunda ise hemen 'git git' diye bağırarak tavuklara ikram eden, yavru horozlara göz açtırmayan, tavukları hırpalayan horozla babası arasında benzerlikler olduğunu fark eder. Babası da tıpkı horozun kümeste tavuklara ve yavru horozlara hükmettiği gibi evde kendisine, annesine ve kardeşlerine hükmetmektedir. Bu durumdan rahatsız olan genç kız bir gün annesine babasının bu tavırlarını şikâyet eder. Annesinin bütün erkeklerin böyle sert, kadınların ise yumuşak olduklarını, dünyanın nizamının böyle kurulmuş olduğunu söylemesi, genç kızı iyice hiddetlendirir. Bu münakaşanın üzerine genç kız kümese giderek eline aldığı taşı horoza fırlatır ve onu öldürür.

SEFAD, 2020; (43): 1-18 
"Dünyanın Nizamı" isimli hikâye ise genç kızın evlenmeyi istememe kararındaki değişimi ve bu değişime neden olan rüyayı konu edinir. Hikâyenin başında genç kız, evlenmeye karşı çıkmasının densizliğinden ve her kız gibi kocaya varmasının gerekliliğinden bahseder. Kararındaki bu değişime sebep olan olayın ise öldürdüğü horozun rüyasına girmesi olduğunu söyler. Genç kızın rüyasına giren horoz, ona kendisini neden öldürdüğ̈̈ne dair hesap sorar, tıpkı kümesteki tavuklara yaptığı gibi onu hırpalar, kanatları altına alır, gagalar. Tavukların kendisinin varlığından dolayı mutlu olduklarını, gagalandıkça, dövüldükçe sevindiklerini; kendisi olmadığında ise yumurtlamayı bıraktıklarını, tembelleştiklerini söyler. Rüyanın sona ermesiyle uyanan genç kız acının, zulüm görmenin zevkini duyar. İstemeye istemeye yataktan kalkarak bahçeye iner ve kümesin düzeninin bozulduğunu, tavukların yumurtlamayı kestiklerini, tembelleştiklerini, sürekli kötürüm gibi yattıklarını düşünür. Bunun üzerine tıpkı kümesin bir nizamının olduğu gibi dünyanın da bir nizamı olduğunu ve bunun bozulmaması gerektiğini anlar. $\mathrm{Bu}$ iki hikâyenin modernist unsurlar açısından değerlendirilmesi aşağıdaki başlıklar doğrultusunda yapılmıştır.

\section{Yabancılaşma}

Yabancılaşmanın temelinde insanın özünün, yaratıcılık ve etkinliğinin bastırılması, çarpıtılması ve işlevsiz hâle sokulması bulunmaktadır (Akyıldız, 1998). Bunun metaya dayalı yabancılaşma ve varoluşsal yabancılaşma olmak üzere iki boyutu vardır. İnsan-meta ilişkisine dayalı yabancılaşmada insanın teknolojik manada ürettiklerinin kontrol altına alınamaz duruma gelmesi önemli bir etkendir. Buna göre insan ürettiklerinin manasına nüfuz edememekte, bir anlamda ürettiklerinin esiri olmaktadır. Bu durum sürekli ve değiştirilemez bir niteliğe ulaştığında 'manasız bir kendini tekrar etme' şekli almakta ve insan ürettiklerine, üretim yerine, üretim şekline yabancılaşmaktadır. Burada varoluşal anlamdaki yabancılaşma üzerinde daha bir önemle durmak gerekir. Çünkü toplumun hemen her üyesi Marksçı yabancılaşmaya uğrarken varoluşsal yabancılaşmaya daha çok kendi varlığı üzerinde düşünebilenler uğramaktadır. Varoluşsal yabancılaşma kısaca kişinin toplum içindeki varlı̆̆ına, toplum eylemlerine, yerleşik algılara yabancılaşması şeklinde tanımlanabilir. Modernizmin egemen kıldığı akıl, toplum hayatını düzenli kurallar bütünü şekline getirirken ilginç bir paradoksla birey olma özelliklerini de zamanla törpülemiştir. Bu durum bireyle toplum arasında bir mesafe oluşmasını ve çatışmaları beraberinde getirmiştir. Böylece birey kendi varlığı üzerinde çeşitli yönlerden sorgulamalara girişmiştir. Kierkegaard'a göre, (akt. Özaltıok, 2011, s. 19) varoluşsal yabancılaşmanın temel problemi, anlamsızlık ve mutsuzluğun hüküm sürdüğü bir dünyada, insanın kendi benine anlam yükleyebilmesi, kendi özüne ilişkin olarak uygun bir kavrayışa ulaşabilmesi problemidir. Varoluşsal yabancılaşmaya uğrayan birey daha çok iç dünyasına çekilerek toplumdan yalıtılmış bir hayatı seçer. Toplumla ilgili düşünceleri 'ben ve onlar' şeklinde bir ayrışmaya uğrar. Toplumu ve toplum karşısında kendini değerlendirirken eleştirel ve sorgulayıcı bir hesaplaşma içine girer. Eleştirdiği noktalarda genellikle tepkisel olmayan, zaman zaman da aktif reaksiyonlar gösterir. Çoğu zaman bunalım ve sıkıntı içindedir. Bu açıdan bakıldığında "Horoz" hikâyesinde üzerinde durulması gereken asıl temanın yabancılaşma olduğu görülür.

Hikâyenin başkahramanı bir genç kızdır. Hikâye birinci tekil kişi (ben) ağzından anlatılmıştır. Bu nedenle okuyucunun bütün dikkatinin başkahraman üzerinde yoğunlaşması gerekmektedir. İlk cümleden itibaren bu durum sağlanmıştır. "Yine bugün 
derin bir ıstırap içinde kıvranıyordum."(Seyfettin, 2015, s. 947) cümlesi başkahramanın iç dünyasına doğru bir yolculuğa çıkılacağının göstergesidir. Modernizmin edebiyata yansıyan en önemli özelliklerinden birisi de burada ortaya çıkmaktadır. Modern eserler kahramanların daha çok iç dünyalarını, hesaplaşma ve sorgulama süreçleriyle birlikte bir anlam arayışını işlemektedir. Bu cümledeki en önemli kelimeler 'yine' ve 'ıstırap' şeklindedir. Buradan başkahramanın bir süreden beri bir iç sıkıntısı nedeniyle acı çektiği anlaşılmaktadır. Okuyucu tam bu noktada yabancılaşma kavramı ile karşılaşmaktadır. Yabancılaşma onlar ve ben (genç kız) adlandırmasıyla somutlaşmaktadır. 'Onlar'ın açılımı "annem, babam, kardeşlerim, akrabalarım, hepsi"(Seyfettin, 2015, s. 947) şeklindedir. Onların özelliği genç kıza çılgın nazarıyla bakmak; genç kızın tepkisi ise derin bir ıstırap duymaktır. Bunun nedeni ise kocaya varmak istemeyiş olarak verilir. Hikâyede 'ben' ve 'onlar' ayrımı devam eden bölümlerde de vardır. Örneğin "Niçin olduğunu söylesem gülecekler. Kaçıklğıma hükmedecekler. Fakat bu katî kararımda o kadar haklıyım ki."(Seyfettin, 2015, s. 947) cümlelerinde genç kız ve diğerlerinden oluşan etiketler açıkça seçilmektedir. Bu cümleler ayrıca yabancılaşma bağlamında çevreyle (toplumla) uyuşamama temasına da vurgu yapmaktadır. Genç kızla toplumun uyuşamama hâli açısından eksen 'erkeğe yönelik algı'dır. Toplumun birer üyesi olan diğer genç kızlar açısından erkek; hayallerde, rüya bulutlarından kurulmuş taht üzerinde oturtulan ve adına koca denilen mabuddur. Oysa hikâyenin kahramanı genç kız için erkek; bir ejderhaya benzemektedir. Genç kız ondan ürkmekte, kendisiyle evlenmek isteyen bir erkek çıkınca bağırmaya, çağırmaya, kendini yerlere çarpmaya başlamaktadır. Bu nedenle uyuşmazlık ve anlaşılamama sorunu yaşayan genç kız evde 'deli' olarak adlandırılmakta ve normal olarak kabul edilen çerçevenin dışına itilmektedir.

Hikâyenin başkahramanının yabancılaşmasında ailenin de rolü bulunmaktadır. Aile de bir anlamda topluma yabancılaşmıştır. Genç kız, yaşadığı yeri 'istasyonun uzağındaki tenha köşk' olarak tarif etmektedir. Bu tarifteki 'istasyon, uzak, tenha, köşk' kelimelerinin her biri yabancılaşma temasını öne çıkarmaktadır. Öncelikle ailenin, içinde yaşadığı mekân bir köşktür. Köşk, büyüklüğü itibariyle birkaç nesli aynı anda ve çevreye ihtiyaç hissetmeden barındırmaya elverişli bir mekândır. Bu durum köşkte yaşayanların iletişim konusunda kendileriyle yetinmeleri için yeterli bir gerekçe olabilir. Köşkün tenha olması da ıssızlık, sessizlik ve yalıtılmışlık kavramlarını çağrıştırmaktadır. Diğer yandan istasyon, geliş-gidiş yönünde karşılıklı bir insan hareketliliğinin olduğu kalabalık bir mekânı temsil eder. Köşkün istasyonun uzağında olması çevreden yalıtılmış, toplumla iletişimi zayıflamış bir içeriği anımsatır. Genç kızın ailesini tanıtırken kullandığı ifadeler de bu durumu desteklemektedir. "Biz ailece merdümgiriziz. Ne misafirliğe gideriz ne de bize gelirler."(Seyfettin, 2015, s. 947) cümleleri, ailenin kendi içinde sürdürmeyi tercih ettiği bir yaşam tarzının göstergesidir.

\section{2. İletişimsizlik}

Yabancılaşmaya uğrayan bireyin en belirgin tepkilerinden birisi iletişimsizliktir. Bu durumda birey çevresiyle iletişimi sonlandırır veya en aza indirger. Böylece sadece kendi iç dünyasıyla iletişim hâlini devam ettirir. Hikâyenin kahramanı genç kızda böyle bir durum söz konusudur. Metnin başındaki "Dün tanımadığım ihtiyar bir doktora beni uzun uzadıya muayene ettirdiler. Zavallı adam."(Seyfettin, 2015, s. 947) ifadeleri iletişimsizliğin göstergesidir. Genç kız kendisini muayene eden doktoru tanımamaktadır ve onunla tanışma gereği de hissetmemiştir. İçinde bulunduğu ruh hâlini anlatmadığı için doktor 'âsâbı bozuk' şeklinde yanlış bir teşhis koymuştur. Hâlbuki genç kız bu teşhisin doğru olmadığını bilir. "Ben

SEFAD, 2020; (43): 1-18 
biliyorum. Hiçbir şeyim yok. Sihhatim yerinde. Aklım başımda. Yalnız koca istemiyorum."(Seyfettin, 2015, s. 947) şeklindeki cümleler iletişimi yalnız kendisiyle sürdürdüğünün bir göstergesidir. Koca istemeyişinin sebebini soranlara "Niçin? diyenleri, niçinse niçin... diye tersliyorum."(Seyfettin, 2015, s. 947) şeklinde verdiği cevap da çevresiyle iletişimden kaçındığını destekler niteliktedir. Hikâyede iletişimsizlik durumunu destekleyen başka bir unsur da kahraman seçiminde gizlidir. Hikâyede anne, baba, genç kız ve erkek kardeşler vardır. Genç kız, duygularına ortak olacak, düşüncelerini destekleyecek, ona yalnız olmadığı hissini yaşatacak bir kız kardeşten mahrumdur. Bu nedenle aile içinde anlaşılmadığını düşünerek çevresiyle iletişimsizliği seçmiştir.

\section{Sisyphos (Saçma, Uyumsuz) Kompleksi}

Sisyphos, Yunan mitolojisinde daha çok kurnazlığıyla tanınmaktadır. İşlediği bir suçtan dolayı yakalanan Sisyphos'a bir ceza düşünülür. Sonunda kocaman bir kayayı elleriyle iterek yüksek bir dağa çıkarmaya mahkûm olur. Fakat Sisyphos kayayı dağın zirvesine her çıkarışında kaya ağırlığından dolayı tekrar aşağıya düşmektedir. Böylece Sisyphos, bütün yaşamı boyunca aynı işi tekrar etmek durumunda kalmış ve bu durum ona verilebilecek (kendisi açısından) en saçma ceza olmuştur. Modernist eserlerde kahramanlar adeta Sisyphos'ta olduğu gibi her an aynı şeyi tekrarlayan ve bunun sonucunda anlamını yitirmiş bir hayat sürmek zorunda kalan insanlar olarak çizilmişlerdir. Yerine getirdiği işte, ürettiğinde anlam aramayan, sadece yaşamak için üretmek durumunda olan insanın sonu ne yazık ki yabancılaşma olmuştur.

Hikâyede genç kızın çiftlik olarak nitelendirdiği köşkteki yaşamı son derece sıradan ve her gün yerine getirilen vazifelerin tekrarından ibarettir. Bu burum kahramanın adeta bir Sisyphos kompleksi içinde bulunduğunu gösterir. Modern insanın en büyük sorunlarından birisi her gün mekanik tekrarlardan ibaret olarak yerine getirdiği ve anlamina bir türlü nüfuz edemediği davranışlar zinciridir. Bu bağlamda insan Sisyphos gibi sanki 'kumandalı bir özgürlük' alanı içinde, anlamsız ve kendini tekrar ederek yaşamaktadır. Hikâyedeki genç kızın şu ifadeleri bu açıdan önemlidir. "Bütün vaktim babamın verdiği fennî, ahlaki kitapları okumakla, kardeşlerimin manasız, münasebetsiz iddiaların dinlemekle geçer. Okumadığım zaman tavukların bahçesindeyim, yemlerini ben veririm. Folluktan yumurtalarım ben toplarım. Kuluçkalara ben bakarım."(Seyfettin, 2015, s. 947). Bu cümlelerde sürekli 'ben' zamirinin kullanılması, geniş zaman tercih edilerek yapılan işlerin tüm zamanlara yayılması bireyin yerine getirmekten pek hoşlanmadığı, kendisini geliştirmekten uzak vazifelerin tekrarına işarettir. Genç kız aynı durumu tavuklarda da gözlemlemektedir. Ona göre tavuklar sevimli, kendi hâllerinde, saf ve masum varlıklardır ve yaptıkları vazife hep aynıdır. Hayatları tam bir vazife ve fedakârlık destanıdır. "Bizi beslemek için muntazaman yumurtlarlar. Civciv çıkarmak için haftalarca aç, susuz, uykusuz, güneşsiz, eğlencesiz yumurtaların üstlerinde yatarlar, kendi hararetleriyle yavrularm canlandirırlar."(Seyfettin, 2015, s. 947-948). Hikâyede tavuk simgesiyle yansıtılmak istenen anne-kadın için de aynı durum geçerlidir. Onlar da adeta hiç sorgulamadan üretir, besler ve hizmet ederler. Hikâyede tavukların karşısındaki güç olarak tasvir edilen bir de horoz bulunmaktadır. Horoz da aslında her gün aynı işleri yapar ancak bunu sadece kendisine karşı sorumlu bir patron edasıyla yerine getirir. Genç kız horozu 'mağrur kral, müstebit bir Neron, dehşetli bir hodgâm, nefsiyle meşgul bir geveze' olarak tanımlamaktadır. Köşkün kümesindeki bu horoz tavuklara zulüm eder, onları hırpalayarak yaralanmalarına neden olur, yemlerini elinden alır. Kümesteki küçük horozların ötmesine 
izin vermez. Kü̧̈ük horozlar ötmek isteyince onları yaralayarak susturur. Bu yönüyle 'mütehakkim, maskara ve şarlatan'dır.

\section{Anomi}

Anomi, Fransız sosyolog Emile Durkheim tarafından geliştirilen bir kavramdır. Sosyal anlamda düzenin işlememesi, bozulması sonucunda yaşanan kuralsızlık durumunu ifade eder. Psikolojik anlamda ise normlar ve değerler arasında yaşanan çelişkilerin anomiyi ortaya çıkardığı söylenebilir. Durkheim bu kavramı genellikle bireyin toplumla bütünleşmesini engelleyen düzensizlik durumu şeklinde düşünmektedir. Kısaca anomi, psikolojik olarak toplumla uzlaşma sağlayamayan bireyin içinde bulunduğu anlamsızlık, kararsızlık ve istikrarsızlık durumunu anlatan bir kavramdır. Anomik durumda bulunan birey kendini toplumdan soyutlayarak genel bir iletişimsizlik hâlini seçer. Hayatı anlamsız, boş bir süreç olarak algılar. Genellikle kendini değersiz görme eğilimindedir.

Hikâyede genç kız babasıyla horoz arasında bir benzerlik kurar. Babasının gözleri de horozunkiler gibi dik ve yuvarlaktır. Başındaki kırmızı fesi horozun ibiklerini andırır. Horoz gibi öfkelidir. Annesi ve kardeşleri babasının yanında ağızlarını açamazlar. Aslında içinde yaşadıkları ev de bir kümese benzemektedir. Babasının odası evin en iyi odasıdır. Horoz gibi başköşeye kurulmaktadır. Evin diğer bütün üyeleri ise adeta birer tavuk gibidir. Babasının davranışları da tıpkı horozun davranışları gibidir. "Hizmetçileri döver, uşakları kovar, mutfă̆a karışır, kardeşlerimi azarlar, anneme gık dedirtmez, bana göz açtırmazdı. Evde münhasıran yalnız o vardı. Kümeste horozun olması gibi. Biz hep onun esirleri."(Seyfettin, 2015, s. 950). Bu ifadeler genç kızın evdeki babasıyla kümesteki horozu aynı düzlemde algıladığını göstermektedir. Kümeste horozun, evde babasının benzerliğini fark ettikten sonra genç kız sorgulama bağlamında bir adım daha öteye geçer ve bir gün annesine babasının tavır ve davranışlarından şikâyet eder. Aldığı cevap çok manidardır. "Yavrum, dedi. Bütün erkekler böyledir. Bütün erkekler böyle mi? Elbet. Hepsi böyle sert mi olur? Elbet. Kadın yumuşak, erkek sert." (Seyfettin, 2015, s. 950). Bu cevaba itiraz etmek üzereyken annesi sözlerine devam eder: "Dünyanın nizamı böyle kurulmuş. Kadın, kadın! Erkek, efendi! Namuslu insanlar bu kaidenin dışına çıkamazlar."(Seyfettin, 2015, s. 950). Genç kızın, annesiyle yaptığı bu konuşmadan sonra sinirleri bozulmuş ve son derece üzüntülü bir ruh hâline bürünmüştür. Bu durum genç kızın psikolojik anlamda dengesinin bozulduğunu, kurulu içsel düzenin travmaya uğradığını ve anomiye tutulduğunu göstermektedir. Bundan kurtulmak ve kurulu iç düzeni yeniden tesis etmek için iki çözüm yolu geliştirir. Bunlardan birincisi horozu öldürmek, ikincisi ise kesinlikle kocaya varmamak yani evlenmemektir. Çünkü o, ne istediğini bilmektedir. Hikâyenin sonuna doğru kullanılan "Ben horozsuz bir kümes yani kocasız bir ev istiyorum. Efendisiz, kumandasiz, amirsiz, emirsiz bir hayat istiyorum."(Seyfettin, 2015, s. 951) ifadeleri bunu göstermektedir.

\section{Pasif İsyan}

Pasif isyan, varoluşsal anlamda yabancılaşan insanın topluma, davranış biçimlerine vb. ilişkin yaptığı eleştirilerin, sorgulamaların kendi içinde başlayıp bitmesi, eyleme dönüşmemesidir. Bu durumda birey iletişimsizlik hâlini seçerek soyutlanır ancak bunu eylemlerine yansıtmaz. Benimsemediği alışkanlıklar, davranışlar, algı biçimleri olsa da toplumu değiştirmeye çalışmaz, sadece kendisini bunlardan ayrı görür.

Hikâyede pasif isyanla ilgili cümle düzeyinde bazı değiniler bulunmaktadır. Genç kız uzun süre gözlemlediği horozun kümesteki tavukların başına bir bela olduğuna karar 
vermiş ve onu öldürmüştür. "Geçen hafta onu... Gayrn ihtiyari bir hiddet içinde öldürdüm. Fakat bu kaç senenin birikmiş intikamıydr."(Seyfettin, 2015, s. 948). Bu cümlelerde dikkat çeken ifadeler 'fakat' ve 'kaç senenin birikmiş intikamı' şeklindedir. Genç kız horozu öldürdüğünü söylemekte ancak kendisini müdafaa anlaminda bunun bir anlık hiddetten dolayı olmadığını da cümlesine ilave etmektedir. Buna gerekçe olarak da birikmiş bir intikam duygusunu dile getirmektedir. Bu ifadeden hareketle okur, genç kızın seneler boyunca horozla ilgili duygusal olarak tepki duyduğunu ancak bu tepkinin eyleme geçmediğini anlamaktadır. Yani genç kız pasif bir isyan hâli yaşamaktadır. Aslında bu pasif isyan görünüşte horozla ilgili olsa da arka planda 'erkek' kimliğini temsil eden babasının horoza benzer tavır ve davranışlarına karşıdır. Genç kızın bu pasif isyanı annesiyle konuşmasına kadar sürmektedir. Bu konuşmada erkeklerin tıpkı horoz gibi tartışmaya açık olmayan bir üstünlük ve hâkimiyet alanına sahip olduklarını, annesinin de bunu kabullendiğini anlayan genç kız pasif isyanı tepkiye dönüştürmüştür. Horoza yönelik pasif isyanı onu 'öldürmek'; erkeğe yönelik pasif isyanı ise 'evlenmeyi reddetmek' olarak eyleme döker. Böylece horozu hayattan, erkeği hayatından çıkarmış olur.

\section{Kahramanın Silikleşmesi (Genelleşmesi)}

Edebiyatta modernist etkinin hissedildiği dönem öncesi eserlerde kahramanların genellikle idealleri uğruna çevrelerini değiştirmeyi önceleyen bir yaklaşımları bulunmaktadır. Bunlar kendileri, aileleri, ait oldukları grup ya da toplum, nihai olarak da bütün insanlık adına büyük eylemlere girişme cesaretine sahip kahramanlardır. Daha çok yansıtmacı roman ve hikâyelerde işlenen bu kahramanlara örnek olarak Julien Sorel, Jean Valjean, Kuyucaklı Yusuf verilebilir. Bu türden kahramanlar okuyucunun karşısına fiziksel, ruhsal ve toplumsal yönlerinin tasvir edilmesiyle çıkarlar. Birer isimleri vardır ve okur bu isimleri hiç unutmaz. Edebiyatta modernist etkiyle birlikte kahramanın ele alınış biçimleri de değişmiştir. Kahramanlar artık büyük dava ve idealler uğruna eyleme geçmek yerine kendi dünyalarına çekilmişlerdir. Onlarla ilgili olarak daha çok toplumla uyuşamama, iç hesaplaşmalar, bunalım, intihar gibi kavramlar gündeme gelmektedir. Deyim yerindeyse isim ve cisim önemli değildir artık. Önemli olan, okurun kendi dünyasıyla kahramanın dünyası arasında kurabildiği bağdır. Bu nedenle bu türden eserlerde kahramanlar adeta silikleşir, genelleşerek iç dünyalarıyla okurun karşısına çıkarlar.

"Horoz" hikâyesinde okur, tenha bir köşkte yaşayan bir aileyle karşı karşıyadır. Aile üyeleri arasında baba, anne, genç kız ve bu genç kızın erkek kardeşleri bulunmaktadır ancak bu kahramanların hiçbirine isim verilmemiştir. Hikâyede en baskın kahraman genç kızdır. Etrafındaki olayları, durumları gözleyerek, bunları sorgulayarak, benzerlikler, akıl yürütmeler kurarak hayatına bir yön vermeye çalışır. Bu baskın özelliklerine rağmen kendisine bir isim verilmemiş olması kahramanın silikleşmesine bir örnektir. Genç kızla ilgili olarak dikkatleri çeken başka bir durum hikâye boyunca hiçbir fiziksel özelliğinin verilmemiş olmasıdır. Böylece okurun zihninde ismi ve cismiyle bir karakter değil, sadece bir düşünce ve imaj oluşturulmuştur. Buradaki amaç kaderini değiştiren ve bu eylemiyle benzer insanlara örnek olan bir karakter yaratmak değil, modern insan kitlesinin herhangi bir üyesinin zihinsel takibini yapmaktır. Bu durum Franz Kafka ve Türk edebiyatından Yusuf Atılgan'ın eserlerinde sıklıkla karşımıza çıkar. Hikâyede ayrıntılı bir şekilde tanıtılan babanın ve yönlendirici konumundaki annenin isimlerinin olmaması da bu durumu desteklemektedir. 


\section{Arketip ve Anne Arketipi}

Analitik psikolojinin kurucusu Carl Gustav Jung, bilinçdışı kavramını ikiye ayırmaktadır. Bunlardan kişisel bilinçdışı bireyin deneyimlerini; kolektif bilinçdışı ise evrensel insanlık deneyimlerini içerir. Kolektif bilinçdışı, kişinin yaşam sınırlarını ve deneyimlerini aşan, bütün insanlığa ait, simgelerin kendiliğinden üretildiği birey ötesi bir alandır (Jung 2006, s. 155). Geçmişteki yaşantıların kalıntıları ise kolektif bilinçdışının imajları olan arketipler olarak belirir. Modernist yazarlara göre insanlığın ortak bilinçaltında birçok gerçeklik saklı durmaktadır. Bu amaçla arketip unsuru modernist eserlerde yoğun olarak kullanılmıştır.

Edebiyatta en çok kullanılan arketip anne arketipidir. Yürek'e göre (2005, s. 79) birincil ve ikincil ilişkilerin giderek zayıfladığı modern toplumlarda birey için anne, hem karşılıksız sevginin hem de mutlak güvenli olanın öznesidir. Bu yüzden anne figürü ve anne arketipi yalnız, mutsuz bireyin arayışlarının temel yapı taşlarından biridir. Dolayısıyla modernist romanlarda okurun karşısına sıklıkla çıkar.

"Horoz" hikâyesinde genç kızın arketip olarak anneye doğru yolculuğu birkaç aşamadan oluşan bir süreç sonrasında gerçekleşmiştir. Bu aşamalar a. kümesteki horozu ve tavukları gözlemleme, b. horozla babası arasında benzerlik kurma, c. tavuklarla kadınlar arasında benzerlik kurma şeklinde açıklanabilir. Genç kız öncelikle 'mağrur kral, müstebit bir Neron, dehşetli bir hodgâm, nefsiyle meşgul bir geveze'olarak nitelendirdiği horozla; hizmetçileri döven, uşakları kovan, kardeşlerini azarlayan ve kendisine göz açtırmayan babası yani 'erkek' kimliğini eşleştirmiştir. Diğer taraftan bir ulviyet ve ahlakiyat abidesi olarak gördüğü tavuklarla anne yani kadın kimliğini aynı düzlemde buluşturur. Bu iki durumu sorgularken çevreden birinin bilgi ve görüşüne ihtiyaç duyar. Çünkü bu düşünceler içinde kendisini yalnız ve çaresiz hissetmektedir. İşte bu yalnızlığına ve çaresizliğine teselli olabilir düşüncesiyle yöneldiği adres annesidir. Dolayısıyla kolektif bilinç dışında kendisine sığınılan, yanında huzur bulunan, güven arayışının simgesi olan anne arketipi hikâyede bu şekilde kendini göstermiş olur.

\section{Freudyen Unsurlar ve Psikanalizm}

19. yüzyılın sonlarında Sigmund Freud'un insanı anlamaya ve açılamaya yönelik görüşleri etrafında beliren psikanalitik kuram kendine din, antropoloji, sosyoloji gibi disiplinlerle birlikte edebiyat alanında da önemli bir yer bulmuştur. Freud sanata, özelde de edebiyata giderilmemiş isteklerin doyurulmasını amaçlayan bir etkinlik gözüyle bakar (Freud, 2000, s. 86). O, yaratma süreci ile nevroz arasında bir bağlantı kurarak sanat eserini yazarın bilinçdışına ittiklerinin, bastırdıklarının bir kanıtı olarak görür. Eserle yazar arasında doğrudan bir ilişki kurar ve eser üzerinden yazarına dair çıkarımlarda bulunur. Bu anlamda yazarlar, onun ifade ettiği biçimiyle gündüz düşleyenlerdir. Freud'a göre tıpkı rüyalarda olduğu gibi yazarın eserinde de psikanalitik açıdan çözümlenmesi gereken semboller vardır. Freud, "Dostoyevski ve Baba Katilliği" isimli makalesinde Dostoyevski'nin Karamazov Kardeşler eserindeki olaylarla yazarın gerçek yaşamındaki olayları örtüştürerek onun yaratıcı bir sanatçı, nevrozlu bir hasta, ahlakçı ve günahkâr biri olduğunu ileri sürer. Yine Freud, kız ve erkek çocuğun karşı cinsteki ebeveynine ilgi duymasını, erkek çocuğun babayı öldürüp anneye sahip olma isteğini ve iğdiş edilme korkusunu açıklayan karmaşayı Sofokles'in Kral Oidipus eserinden hareketle 'Oidipus Kompleksi' olarak isimlendirir. Dolayısılla Freud'un edebiyat eserlerine yönelik yaptığı çalışmalar eserden hareketle yazarı çözümlemeye yönelik olarak değerlendirilir. Bu çalışmadaki psikanalitik (Freudyen) unsurlar bilinçdışı ve rüya, 
üst ben/toplumsal uyumsuzluk, ben/toplumsal uyum ve cinsellik başlıkları altında ele alınmıştır. Araştırmaya konu olan "Horoz" hikâyesinde erkek despotizmi ve genç bir kızın buna karşı geliştirdiği tepki vurgulanmaktadır. "Dünyanın Nizamı" hikâyesinde ise genç kız, var olan kurulu düzeni anlamış ve kabul etmiştir. Bu anlayış ve kabul edişin arkasında ise psikanalitik kuramın dünyayı yorumlayış biçimi vardır.

\section{1. Bilinçdışı ve Rüya}

Bilinçdışı, sansür mekanizmasının engeli dolayısıyla bilinç düzeyine ulaşma olanağ olmayan zihinsel süreçleri içerir (Geçtan, 1998, s. 27). Freud'a göre insanın yaşam enerjisi olarak niteleyebileceğimiz libidosunun kaynağı cinsel içgüdülerdir ve dışarı çıkma olanağı bulamayan, gücünü cinsel içgüdülerden alan istekler bilinçdışına itilirler. Bu yönüyle bilinçdışı kapalı bir özellik gösterir. Bilinçdışı bilinmez, kestirilemez dolayısıyla karanlık bir alan özelliğinde olsa da dışavurum yoluyla zaman zaman kendini görünür kılar. Onun kendini görünür kılma yolları dil sürçmeleri, unutkanlıklar, yanılmalı edimler ve rüyalardır (Perron, 2003, s. 105-107). Bunlar arasında rüya, ayrı bir öneme sahiptir. Çünkü Freud'a göre rüya bilinçaltına giden kral yoludur. Her rüyayı bilinçdışı ile bağlayan bir göbekbağı vardır (Mannoni, 1992, s. 51). Freud rüyaların yorumlanmasını kendisinden öncekilerin kabul ettikleri gibi fantastik bir iş olarak değerlendirmemiş ve rüyaları yorumlamak için bilimsel bir yöntem geliştirdiğini iddia etmiştir. Freud'a göre rüya, bir arzunun gerçekleşmesidir (Freud, 2014a, s. 147). Rüya, baskı altında tutulan ve doyurulmayan isteklerin başka bir görünümde gerçekleşmesidir.

Dünyanın Düzeni isimli hikâyede genç kız rüyasında öldürdüğü horozu görür. Horoz, genç kıza kendisini neden öldürdüğüne dair bir dizi soru sorar. Horoz, sorduğu sorular karşısında genç kızın zihninden geçen yantları bilir ve tüm bu yanıtları kendi düşünceleriyle tek tek çürütür. Büyük bir kısmı bu rüyaya ayrılan hikâyede genç kızın fikirleri gördüğü rüyada horozla girdiği fiziksel ve iletişimsel münasebet neticesinde tamamen değişir. Rüyanın görülme zamanı sabaha doğrudur. Bunu, kahramanın rüyayı gördükten sonra balkona geçtiği sırada annesinin ona, sabah rüzgârına karşı üşütmemesi konusunda yaptığı uyarıdan anlarız. Freud'a göre $(2014$, s. 28) yakın geçmişe ait olan izlenimler rüyada sabaha karşı ortaya çıkar. Birbirinin devamı niteliğinde olduğunu söylediğimiz bu hikâyelerin ilkinde kahraman horozu öldürür, ikincisinde de rüyayı görür. "Dünyanın Nizamı" isimli ikinci hikâyede kahraman bir ay geçmeden fikrinin değiştiğini, fikrinin değişmesine de öldürdüğü horozun hayalinin neden olduğunu söyler. Dolayısıyla iki hikâye arasındaki zaman farkının bir aydan daha kısa ve görülen rüyanın yakın geçmişe ait olduğu açıtır.

Görülen rüya, kahramanın bilinçdışını ortaya koyması açısından önemlidir. Hikâyedeki rüya kâbusla karışıktır. Bu noktada kâbus ve rüya arasındaki ayrıma değinilir ve bu ayrım hikâyede "kâbusta insan kımıldayamaz, ağzını açamaz, sesini çıkaramaz; rüyada ise insan serbesttir, bir dereceye kadar iradesine sahiptir."(Seyfettin, 2015, s. 952) ifadeleriyle açılanır. Burada, rüyada iken kişinin iradesinin olduğundan bahsedilmesi önemlidir. Çünkü irade ile kast edilen aslında bilinçli olarak istenen, arzulanan, tercih edilen durumdur. Hikâyeye göre genç kız önce korkunç bir kâbustadır ardından bu kâbus rüyaya döner. Kâbustan rüyaya geçiş, horozun gürleyerek genç kızın üzerine atlaması ile gerçekleşir. Genç kız bu durumu, "kâbus bozuldu, rüya başladı" (Seyfettin, 2015, s. 952) ifadeleri ile anlatır. Dolayısıyla horozun genç kızın üzerine atlamasıyla birlikte kâbus sona ermiş, haz duyulan kısım başlamıştır. Bu durum, genç kızın horozu bir arzu nesnesi haline getirdiğini ifade eder. Burada bilinçdışının 
sızdığı bilinç kısmen devrededir ve arzulanan eylemin yerine rüya konulmuştur. Freud'a göre libidonun tatmin sağlama yollarından başlıcası bilinçaltına itilmiş dürtünün kendisini rüyada göstermesidir. Rüya, bir arzunun gerçekleşmesidir (Freud, 2014a, s. 147). Horozun erkek, tavuğun kadın olarak imlendiği hikâyede kadın olan kahramanın horozu yani erkeği bilinçdışında arzu nesnesi olarak var ettiği anlaşılmaktadır.

Rüya görenin bize anlattı̆̆ı rüya, sık sık çevirisi yapılması gereken bir metne benzetilmiştir Freud tarafından (Mannoni, 1992, s. 53). Bu noktada Freud, rüya düşünceleri ile rüya içeriği arasındaki ayrımı ortaya koyar. Ona göre rüya düşünceleri ve rüya içeriği aynı konunun iki farklı dildeki versiyonları olarak sunulur. Rüya içeriği, rüya düşüncelerinin başka bir ifade biçimine aktarılması gibidir (Freud, 2014b, s. 5). Genç kızın rüya içeriğini aktarırken kullandığı aşağıdaki ifadeleri yorumladığımızda, bu ifadeleri cinsel birleşim anına gönderme şeklinde okuyabiliriz. "Nefes bile alamıyordum... Her ötüşünde titriyordum... (Horoz için) Karşımdaki büyüyor, büyüyor, adeta bir dev halini alıyordu... Demir pençelerinin altında karyolam zangırdıyor, sanki bir zelzele her tarafı sarsıyordu... (Horoz için) Ben harelene harelene karşımda değişmesine bakarken... Saçlarımı yoluyor, üstümü başımı didik didik ediyordu... Uyandığım vakit ter içindeydim... Yorgan aşağı düşmüştü... Sanki bütün kemiklerim kırılmış..."(Seyfettin, 2015, s. 952-953).

Freud'un ileri sürdüğü önemli düşüncelerden biri de rüyada sansür mekanizmasının varlığıdır. Bu mekanizma, dürtülerin bilinçdışından bilince geçerken bazı değişimlere uğramasına neden olur. Fromm (2016, s. 108) Freud'un sansür mekanizmasını şu şekilde ifade eder: Sanki bir perde arkasında yer alan bu sansür olgusu, gizli düşüncelerin ancak yeterince örtülüp maske taktıkları zaman bilincin sınırlarını geçmesine izin verir. Bu durum, rüyalardaki sembollerin arka planını oluşturur. Freud'a göre açıkça ifade bulamayan dürtüler, rüyada bazı sembollerle ifade edilir. Düşte doğrudan gözükmeyerek kendilerini simgelerle açığa vuran ise en başta genital organlar ve cinsel eylemlerdir (Freud, 2000, s. 73). Rüyada uzun nesnelerle birlikte bıçak, kama, mızrak gibi kesici, delici aletler erkek cinsel organına karşllık gelir (Freud, 2014, s. 90). Erkek imgeleri veya fallik semboller kuleler, roketler, silahlar, oklar, kılıçlar ve benzerlerini içerebilir. Kısacası imgeler dik durur ya da ateş alırsa (patlarsa) fallik bir sembol olabilir (Tyson, 2006, s. 20). Dünyanın Düzeni isimli hikâyede rüyanın anlatıldığı bölümde horozdan sivri, hançer gagalı (bu gagadan çıkan kelimeler de oka benzetilir) tuğlu, mahmuzlu, kılıçlı biri olarak bahsedilir. Dolayısıyla kullanılan bu tip ifadelerle erkekliğe ve erkek cinsel organına göndermede bulunulduğu açıktır.

\section{2. Üst Ben/Toplumsal Uyumsuzluk}

Freud yapısal kişilik kuramında benliği üç bölüme ayrılan bir bütün olarak değerlendirir. Bu bölümler id, ben ve üst bendir. Freud'a göre (2001， s. 102) id değer yargılarından, iyiden, kötüden, ahlaktan habersizdir ve haz ilkesine sıkıca bağlıdır. Bu anlamda id akıldışı ve ilkeldir. İd, beni kendi enerjisi doğrultusunda üst ben ise töre, ahlak, din gibi toplumsal kontrol mekanizmalarıyla yönlendirmeye çalışır. İd ve üst ben arasında sıkışan ben, bu iki itkiyle uzlaşmaya çalışır fakat onlarla bir araya gelmek çoğu zaman oldukça zordur.

Ömer Seyfettin "Horoz" ve "Dünyanın Nizamı" isimli hikâyelerde çatışmayı evlilik üzerinden gerçekleştirir. Yazarın çatışma unsuru olarak evliliği seçmiş olması tesadüfî olarak düşünülemez. Evlilik toplumsal bir birlikteliktir. Kadın ve erkek arasındaki kültürel uyum, bu kültürün çocuklara aktarılması, nişan, düğün organizasyonları evliliğin kültürel 
bir boyuta sahip olduğunu ortaya koyar. Giddens'e göre de (2012, s. 247) evlilik iki yetişkin birey arasındaki toplumsal olarak kabul edilen ve onaylanan bir cinsel birleşimdir. Hikâyelerde evlilik gibi sosyal bir kurum üzerinden ben ile üst ben arasındaki mücadeleyi okuruz. Ana kahraman olan genç kız kümes hayatına dair gözlemlerinden hareketle evi kümes, evlilik hayatını ise kümes yaşamı ile özdeşleştirir ve kadın-erkek rolleri bağlamında evlilik kurumunu sorgular. Onu bu sorgulamalara sevk eden toplumsal cinsiyet rolleri ve bu rollerin kabulüne ilişkin toplumsal öğretilerdir.

Toplumsal cinsiyet, özellikle genç kızın anne ve babasının birbirlerine karşı konumları; var olan bu konumun kabulüne ilişkin yargı ise anne aracılığı ile ortaya konur. Baba, aile üyelerine söz hakkı tanımayıp evin nimetlerinden yararlanma hakkını kendinde gören, ev yaşamın öfke ve şiddetle dizayn eden, kendi sözünü geçiren, evi idare eden biri iken anne, babanın tüm emir ve buyruklarına boyun eğen, otuz yıldır birlikte olmalarına rağmen ondan korktuğu için yanında sigara dahi içemeyen fakat bu durumu, yadırgamak yerine erkeğin efendi oluşunun doğal bir sonucu olarak gören taraftır.

Hikâyede bu tip toplumsal öğretilerin savunucuları olarak anne, aile ve akrabalar karşımıza çıar. "Horoz" isimli hikâyenin daha ilk sahnesi genç kız ile ailesinin karşı karşıya geldiği olay ile başlar. Genç kızın kocaya varmak istememesi üzerine ailesi onu doktora götürür. Hikâyenin henüz giriş kısmında böyle bir olaya yer verilmesi, toplumsal yaşamın en küçük birimi olan ailenin, genç kızın karşısında yer alan sosyal engel unsuru olduğunu gösterir. Ailenin, akraba üyelerinin genç kızın evlenmek istememesi üzerine ona çılgın gözüyle bakmaları yine toplum baskısının açık bir şekilde ifade edilişidir. Bunlar arasında anne, genç kızla gerçekleştirdiği karşılıklı konuşmalarda, toplumun mesajını ona doğrudan iletir. "Elbet. Kadın yumuşak! Erkek sert! Dünyanın nizamı böyle kurulmuş! Kadın, kadın! Erkek efendi! Namuslu insanlar bu kaidenin dışına çıkamazlar."(Seyfettin, 2015, s. 950). Annenin, geniş çerçevede de toplumun düşünce dünyasını yansıtan bu ifadelerle namuslu insan olmanın ölçütü toplumsal cinsiyet rollerini kabul etmeye bağlanır. Hikâyedeki genç kızın “Ben horozsuz bir kümes yani kocasız bir ev istiyorum"cümlelerine karşılık anne karakteri yine üst beni/toplumsal öğretiyi temsil eder biçimde "Dünyanın nizamını bozacaksın, her kadına mutlaka bir erkek lazım!" (Seyfettin, 2015, s. 951) ifadeleriyle karşı çıkar. Dünyanın nizamı ile kast edilen toplumsal düzenin devamlılığına temel teşkil eden aile birliğinin ve toplumsal kadınlık erkeklik kimliklerinin korunmasıdır.

Freud'a göre (1941) toplumun ilk yasası, kabile erkeklerinin bir araya gelip topluluktaki tüm kadınlara sahip olan babayı öldürmelerinin sonucunda oluşur. Buna göre babayı öldüren erkekler pişmanlık duyarlar ve babanın öldürülmesini yasaklarlar. Lacan (2012) bu durumu babanın adı (simgesi) olarak açıklar. Ona (2012) göre babanın biyolojik olarak var olması değil, simgesel olarak aktarımı söz konusudur. İncelenen "Horoz" hikâyesinde de babanın simgesel olarak annenin söyleminde yaşatıldığına tanık oluruz.

Annenin, erkeğin otoritesine karşı itaatkâr yaklaşımı, ailenin toplumsal bir görev olarak kabul ettikleri evliliği yerine getirmesi için genç kıza baskı yapması (doktora götürmeleri, deli demeleri vb), evde ataerkil bir düzenin varlığı, genç kızın üst beni ile beni arasında bir uyuşmazlık yaratır. Öyle ki "Horoz" hikâyesinin henüz ilk cümlesinde, bu uyuşmazlığın genç kızın ruhunda derin bir sstırap yarattığı ifade edilir. Hikâyenin başında bahsedilen uyumsuzluk, sonunda da aynıdır. Benlik ve toplum arasındaki uyum, genç kızın gördüğü bir rüya ile ikinci hikâyede yakalanır. 


\section{3. Ben/Toplumsal Uyum}

Üst ben, ben için bir ideali temsil etmektedir; ben bu ideale uymaya, ona benzemeye eğilim göstermektedir (Freud, 2001, s. 92). "Dünyanın Nizamı" isimli hikâyeye geldiğimizde ben ve üst ben arasındaki uyumu görürüz. Bu uyum hikâyenin ilk cümlelerinden itibaren kendini gösterir. Genç kız artık annesine hak verdiğini, fikrinin değiştiğini, her kız gibi mutlaka kocaya varmasının gerekliliğini anladığını, eski koca istemez kat'î kararına ise gülmekten katıldığını ifade ederek kişiliğindeki dönüşümü hikâyenin başında "Dünyanın düzeni bozulamayacak! Ben de her kız gibi mutlaka bir kocaya varmalıyım" (Seyfettin, 2015, s. 952) ifadeleriyle açıklar. Eski tavrını densizlik ve delilik olarak niteler. Hikâyenin sonunda ise horozsuz kümesi mezarlığa benzetir. Böylece kahraman ataerkil düzene boyun eğmiş ve hak vermiştir. Genç kızın bu dönüşümü kendisini ve toplumu memnun eder. Bu memnuniyetin nedeni, ben ile üst benin uyumudur. Bu uyumun arka planında ise genç kızın gördüğü rüya vardır.

\section{4. Cinsellik}

"Horoz" ve "Dünyanın Nizamı" isimli iki hikâyede tavuk kadın, horoz ise erkek ile bağdaştırılmıştır. Bu bağdaştırmada biyolojik cinsiyetin yanı sıra tavuk ve horozun sahip oldukları ana özellikler etkili olmuştur. Tavukların yumurtlamaları, civciv çıkarmak için haftalarca karanlıkta aç, susuz, uykusuz, güneşsiz, eğlencesiz yumurtalarının üzerinde yatmaları, yavrularını beslemeleri, onları korumaları gibi özellikleri ile kadınlık ve annelik kimliğine; horozun boğazına ve nefsine düşkün olması yönüyle tanımlanması ile de erkek kimliğine işaret edilmiştir.

Illk hikâyede horozun tavukların üzerine atlaması, tüylerini yolması, yatırıp boyunlarını yere sürtmesi, kendisine hizmet ettirmesi onlara karşı yapılan bir zulüm olarak ifade edilir. İkinci hikâyede ise bu zulüm lütuf olarak değerlendirilir. Bu değerlendirmede kahramanın gördüğü rüya etkili olur. Genç kızın rüyasında gördüğü horoz bu kez tavukların yerine genç kızın saçlarını yolar, üstünü başını didikler, kaçmaya çalışırken onu tutarak boynunu yere sürter. Rüyasında horozun gagalamasına, acı çektirmesine maruz kalan genç kız acı duymanın lezzetini tadar. Bunu genç kızın "Hakikaten acının, korkunun, zulüm görmenin, dayak yemenin, gagalanmanın, didiklenmenin pek başka bir lezzeti var! Mazlumun duyduğu bir lezzet ki zalim bunu tahayyül bile edemez."(Seyfettin, 2015, s. 953) ifadelerinden çıkarırız.

$\mathrm{Bu}$ durum sadizm ve mazoşizm olmak üzere iki kavramı gündeme getirir. Cinsel amaç etkin ve edilgin olmak üzere iki biçim altında görünür. Krafft Ebing'e göre (1906: 89) acıtma ve güç uygulama isteği sadizm, acı çekme ve güce maruz kalma isteği mazoşizmdir. Sadistik eylemler kadınlardan ziyade erkeklerdedir. Cinsel ilişki sırasında erkek etkin ve saldırgan bir role sahiptir, kadın ise edilgindir ve savunmada kalır (Krafft Ebing, 1906, s. 59). Mazoşizm esas olarak dişildir (Freud, 2001, s. 149) Bu nedensiz değildir. Erkek cinsellik hücresi etkindir, devingendir, dişi hücrenin peşine düşer; yumurtacık ise devinimsizdir, edilgindir (Freud, 2001, s. 148). Kadını kazanmak, onu zapt etmek erkeğe büyük bir haz verir ve teslim olma anına kadar kendini savunmada tutan kadının utangaçlığı psikolojik açıdan büyük önem taşır (Krafft Ebing, 1906, s. 59).

"Dünyanın Nizamı" isimli hikâyede de kahraman gördüğü rüyayı anlatırken horoz için 'gürbüz bir savaşçı, eski bir şövalye, iri ve muhteşem kanatll, demir pençeli, altından bir zırha benzeyen parlak kıvılcımlı tüyleri olan, gayet güzel bir ejderha' gibi horozun gücünü 
betimleyen güçlü ifadeler kullanır. Güçlü olmak, zenginlik gibi özellikler karşı tarafın cinsel arzularını kamçlayan önemli öğelerdir (Fromm, 2016, s. 46). Görülen rüyanın anlatımında dikkati çeken bir başka husus da genç kızın olayı bir savaş sahnesine benzer şekilde anlatmasıdır. Öyle ki rüya zapt etme ve teslim olma eylemleri arasında geçer. Genç kızın horozdan bahsederken onu erkeği temsil eden bir unsur olarak konumlandırdığını gösteren dil, aynı zamanda horoza sadist genç kıza ise mazoşist özellikler yükler. Zira genç kız horozu yenilmez bir savaşçı şeklinde anlatarak onun kendisine yönelttiği fiziksel güç ve şiddetten haz duyar. Duyulan bu hazzı "Fakat ne tatl, ne hoş, ne ruhanî bir ıstırap ya Rabbi! Bu korkunç rüyaya tekrar dönmek ihtimali olduğunu bilseydim, hemen gözlerimi kapayacaktım."(Seyfettin, 2015, s. 953) cümlelerinden anlarız. Yine rüyada horoz ile kurulan bu münasebetten 'hoş bir istırap' olarak bahsedilmesi de sadist-mazoşist duygular çerçevesinde okunması gereken noktalardan biridir.

\section{SONUÇ}

Edebiyat tarihinde modernist olarak nitelendirilen eserlerde geleneksel kurgulama teknikleri ve üzerinde durulan temalar değişmiştir. Modern tarzdaki eserlerde içerik olarak daha çok birey-toplum çatışması, genel geçer kabul görmüş ve yerleşik hâle gelmiş algıların, davranış kalıplarının sorgulanması, bunalımlı bir ruh hâlindeki bireyin iç sıkıntısı işlenmektedir. Bu durum yabancılaşma, anomi, bilinçaltı, arketip, cinsellik, saldırganlık gibi unsurların eserlerde sıklıkla yer almasını sağlamıştır. Diğer taraftan içeriğin okuyucuya iletilmesinde alegorik anlatıma, simgelere büyük önem verilmiştir.

Ömer Seyfettin'in bu çalışmaya konu olan iki hikâyesinde hem içerik hem de kurgu anlamında modernist eserlerin yukarıda sayılan birçok özelliği yer almaktadır. "Horoz" hikâyesinde toplumun değerleriyle uyuşamayan, çevresine yabancılaşmış ve tepki olarak iletişimsizliği seçmiş bir genç kızın düşünceleri konu edilmektedir. Bu hikâyenin dil ve anlatım özellikleri alegori ile örülmüş̧ür. Bu hikâyede horoz-erkek ve tavuk-kadın eşleştirmeleri alegorik bir tarzda sağlanmaya çalışılmıştır. "Dünyanın Nizamı" hikâyesinde ise bilinçdışı ve rüya, üstben/toplumsal uyumsuzluk, ben/toplumsal uyum ve cinsellik başlıklarını içeren psikanalitik kurama dair zengin bulgular elde edilmiştir. Araştırmada elde edilen bu sonuçlar Ömer Seyfettin'in sadece Türkçü milliyetçi yönüyle değil aynı zamanda farklı okuma biçimlerine de açık olduğunu göstermektedir.

\section{SUMMARY}

Omer Seyfettin is known for his stories, although he brings many works of different types to our literature. The writer who could get a storyline out of everything, fits many stories in his 36-year life. Although the writer's stories are mostly read within the framework of national, spiritual and Islamic values, it is closely seen that he enriches his stories with modernist elements. In this study, stories of Omer Seyfettin named "Horoz" and "Dünyanın Nizami" which are the continuation of each other, were attempted to be solved with a modernist perspective. The elements that can form the basis of modernism in the writer's examined stories are alienation, lack of communication, sisyphus absurd (incompatible) complex, anomy, passive rebellion, greying of the hero, archetype and maternal archetype, freudian elements and psychoanalism (subconscious and dream, superego/social incompatibility, ego/social harmony, sexuality).

"Horoz" and "Dünyanın Nizamı", which are the subject of the study, are two stories of Omer Seyfettin, containing modernist elements and being published every five days. 
"Horoz" was published in the 764th issue of Vakit newspaper dated 22 December 1919, and "Dünyanin Nizamı" was published in the 769th issue of the same newspaper dated 27 December 1919. The story "Horoz" is about the decision of a young girl who does not want to marry, and the reasoning behind this decision. In this story, a young girl establishes a similarity between the poultry life of roosters and chickens and the family life of herself, her siblings and her parents. In the first part of the story, poultry life is explained by a young girl, in the context of the roles of roosters and chickens living there. According to her, chickens are cute, in their own world, pure, innocent and extremely devoted creatures. Roosters, unlike chickens, are proud, do not enjoy anything other than cruelty, do not know what duty, sacrifice, affection, compassion, mercy is, they are chatters busy with their toilet and themselves. The young girl, whose anger grows as she observes the poultry life, realizes that there are similarities between her rooster and her father, who eats by himself where there is anything to eat, and when he finds a piece of stone or sand he immediately offers the chickens by shouting 'cluck-cluck', gets hard upon cockerels, and maltreats chickens. Her father rules his mother and siblings at home, just as the rooster rules chickens and cockerels in the house. One day, the young girl who is disturbed by this situation, complains to her mother about her father's attitudes. The fact that her mother said that all men are so hard and women are so soft and that the world is established like this, makes the young girl pretty angry. On this discussion, the young girl goes to the coop and throws the stone she took and kills the rooster.

His story "Dünyanın Nizamı" is about the change in the young girl's decision not to want to marry and the dream that caused this change. At the beginning of the story, the young girl talks about being inconsiderate about opposing marriage and talks about the necessity of getting the husband like every girl. She says that the incident that caused this change in her decision was the dream of the rooster she killed. Entering the dream of the young girl, the rooster requests an explanation of why she killed him, and just as he did with the chickens in the coop, he hurts her, takes under his wings and beaks. He says that chickens are happy for his existence, and when he beaks and beats them; and if it wasn't for him, they would stop laying eggs and become lazy. The young girl, waking up as her dream ends, enjoys the pain and cruelty. Unwillingly, she gets up from the bed and goes to the garden, and thinks that the coop got out of order, that chickens stopped laying eggs, got lazy and that they lie like a cripple constantly. On top of that, she realizes that the world has a system as well as her coop and that it should not be spoiled.

In Omer Seyfettin's two stories that are the subject of this study, there are many features of modernist works mentioned above in terms of both content and fiction. The thoughts of a young girl who does not match the values of the society, who got alienated, and who chose not to communicate was discussed in the "Horoz" story. The language and narrative features of this story are knitted with allegory. In this story, rooster-male and chicken-female matches are tried to be provided in an allegorical manner. And in "Dünyanın Nizamı" story, rich findings were obtained regarding the psychoanalytic theory which includes subconscious and dream, superego/social incompatibility, ego/social harmony and sexuality. These results obtained in the research show that Omer Seyfettin is open not only to the Turkish nationalist side, but also to different reading styles.

SEFAD, 2020; (43): 1-18 


\section{KAYNAKÇA}

Akyıldız, H. (1998). Bireysel ve toplumsal boyutlarıyla yabancılaşma. Süleyman Demirel Üniversitesi İktisadi ve İdari Bilimler Fakültesi Dergisi. 3/3, 163-176.

Akyüz, K. (1995). Modern Türk Edebiyatının ana çizgileri. Ankara: İnkılap Yayınevi.

Çolak, T. (1998). Modernizm-sanayileşme, sanayi toplumu bağlamında ortaya çıkan sosyo-kültürel ve ekolojik riskler.(Yüksek Lisans Tezi). Hacettepe Üniversitesi, Ankara.

Freud, S. (1941). Totem ve Tabu I. (N. Berkes, çev.). İstanbul: Cumhuriyet.

Freud, S. (1967). Cinsiyet ve psikanaliz. (S. Hilav, çev.). İstanbul: Varlık Yayınları.

Freud, S. (1995). Sanat ve sanatçılar üzerine. (K. Şipal, çev.). İstanbul: Yapı Kredi Yayınları.

Freud, S. (2000). Psikanaliz üzerine. (K. Şipal, çev.). İstanbul: Cem Yayınevi.

Freud, S. (2001). Psikanaliz üzerine. (A. A. Öneş, çev.). Ankara: Say Yayınları.

Freud, S. (2014a). Rüyaların yorumu. C. I. (İ. Kırımlı, çev.).Ankara: Alter Yayıncılık.

Freud, S. (2014b). Rüyaların yorumu. C.II. (İ. Kırımlı, çev.).Ankara: Alter Yayıncılık.

Freud, S. (2017). Cinsellik üzerine. (A. A. Öneş, çev.). İstanbul: Say Yayınları.

Fromm, E. (2016). Freud düşüncesinin büyüklü̆g̈ü ve sinırları. (A. Arıtan, çev.). Ankara: Say Yayınları.

Geçtan, E. (1998). Psikanaliz ve sonrası. İstanbul: Remzi Kitabevi.

Giddens, A. (2012). Sosyoloji. (Z. Mercan, çev.). İstanbul: Kırmızı Yayınları.

Gökberk, M. (1999). Felsefe tarihi, İstanbul: Remzi Kitabevi.

Gökmen, A. (2013). Ruhçözümleyici Eleştiri. R. Filizok ve E. Saltık (Ed.)Eleştiri kuramları (s. 66-85). Eskişehir: Anadolu Üniversitesi Yayınları.

Jung Carl, G. (2006). Analitik psikoloji. (E. Gürol, çev.). İstanbul: Payel Yayınları.

Krafft EbingR. V. (1906). Psychopathia sexualis: With especial reference to the anthipathic sexual instinct, a medio-forensic study. (F. J. Rebman, çev.). New York: Physicians and Surgeons Book Company.

Lacan, J. (2012). Babanın Adları. (M. Erşen, çev.). İstanbul: MonoKL Yayınları.

Mannoni, O. (1992). Freud. (V. Atayman ve T. Kurultay, çev.). İstanbul: Alan Yayıncılık.

Özaltıok, B. A. (2011). Yusuf Atılgan'ın romanlarındaki modernist unsurlar.(Yüksek Lisans Tezi). Çukurova Üniversitesi, Adana.

Seyfettin, Ö. (2015). Ömer Seyfettin bütün hikâyeleri.(N. H. Polat, haz.). İstanbul: Yapı Kredi Yayınları.

Tyson, L. (2006). Critical theory today: A user friendly guide. New York: Routledge.

Yürek, H. (2005). Cumhuriyet dönemi Türk romanında modernizmin yeri.(Yüksek Lisans Tezi). Mersin Üniversitesi, Mersin. 